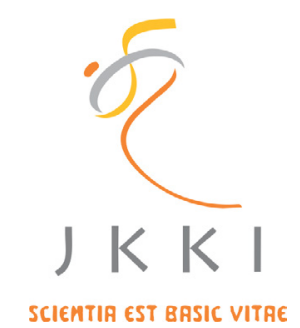

Jurnal Kedokteran dan Kesehatan Indonesia

Indonesian Journal of Medicine and Health

Journal homepage : https://journal.uii.ac.id/JKKI

\title{
Fragmented teaching and compartmentalized learning
}

Cheng Hwee Ming*1

${ }^{1}$ Department of Physiology, University of Malaya, 50603 Kuala Lumpur, Malaysia

\begin{tabular}{|c|c|}
\hline & GUEST EDITORIAL \\
\hline ARTICLE INFO & here is much talk about the integrated medical syllabus, a curriculum \\
\hline $\begin{array}{l}\text { *Corresponding author: } \\
\text { chenghm@ummc.edu.my }\end{array}$ & $\begin{array}{l}\text { 5-6 undergraduate years. I wish to share some thoughts from my } \\
\text { journey as a physiology teacher for } 30 \text { plus years at the medical school in }\end{array}$ \\
\hline DOI : 10.20885/JKKI.Vol10.Iss2.art1 & $\begin{array}{l}\text { Universiti Malaya, Kuala Lumpur. } \\
\text { More basic to the pursuit of integration between basic and clinical }\end{array}$ \\
\hline $\begin{array}{l}\text { Copyright @2019 Authors. } \\
\text { This is an open access article } \\
\text { distributed under the terms } \\
\text { of the Creative Commons At- } \\
\text { tribution-NonCommercial } 4.0 \\
\text { International Licence (http:// } \\
\text { creativecommons.org/licences/ } \\
\text { by-nc/4.0/). }\end{array}$ & $\begin{array}{l}\text { sciences is the need to help students interlink within physiological systems. } \\
\text { This intra-physiological integration is quite often inadequate among my } \\
\text { students and is also evident among students globally as observed from } \\
\text { analysis of the performance during the International Physiology Quiz } \\
\text { competition I chair annually in Malaysia.1,2 } \\
\text { Let me give some common incidences of fragmented, disintegrative } \\
\text { learning. } \\
\text { Cardio-renal physiology } \\
\text { The student tends to treat the short term/long term blood pressure } \\
\text { control as distinctly separate entities. This situation is perhaps partly } \\
\text { due to our fault as educators, in our segmental, sequential teaching when } \\
\text { the CVS (short-term) and renal (long-term) aspects of blood pressure } \\
\text { regulation are taught, separated by several weeks. One regular missed } \\
\text { the integrative point is the failure of the student to appreciate that the } \\
\text { renal sympathetic action is part of the short-term, baroreflex sympathetic } \\
\text { compensatory response to hypovolemia/hypotension. }\end{array}$ \\
\hline
\end{tabular}

Respi-renal physiology

The topic of $\mathrm{pH}$ control is a useful area to help students inter-weave lung and kidney functions. ${ }^{3}$ Respiratory physiology alone can give students the narrow impression that carbon dioxide is merely a metabolic byproduct. However, when $\mathrm{CO}_{2}$ is considered in $\mathrm{pH}$ regulation, it is seen as a component of the major chemical buffer system in the ECF. Besides blood $\mathrm{pH}$, the partial pressure of $\mathrm{CO}_{2}$ is also a regulator stimulus for varying the degree of renal tubular hydrogen ion secretion/bicarbonate reabsorption and synthesis. The student should be reminded that $\mathrm{CO}_{2}$ is also a vasodilator and an enhancer of haemoglobin-oxygen unloading. The wonderful of this nature co-incidences enable our body to fulfil the greater demand for oxygen during physical activity (cardio-respiratory physiology). ${ }^{4}$

Sodium physiology

One common difficulty I found among students is to distinguish between sodium Concentration and sodium Balance homeostasis. I start my lecture by drinking some water and make the point that if I had swallowed a large volume of water, my sodium concentration [Na])decreases but my sodium balance, related total body sodium is unchanged.

Right from the first week of the medical curriculum, body fluid lectures ought to include that the ECF [Na] and ECF volume control (linked to sodium balance) are two quite separate physiology. It is worth stressing that $[\mathrm{Na}]$ control is synonymous with osmoregulation and water balance. Thus osmoreceptors 
are functionally [Na] sensors, while Volume sensors operate in the context of sodium balance homeostasis. This will then lead to the concept that [Na] is under ADH control (osmoregulation) and not as often misconceived, under the renin -angiotensin aldosterone (RAS) family of hormones. Instead, RAS maintains sodium balance/ECF volume that is associated with blood volume/pressure regulation.

We can model the integration between the brain and the kidneys for the students. The brain hypothalamic neurons (osmoreceptors and $\mathrm{ADH}$ ) are involved with water transport in the kidneys for [Na] control. On the other hand, the brain stem trigger for increased sympathetic activity also releases renin that activates sodium conservation mechanisms during negative sodium balance.

Increasingly when physiological information becomes are detailed and much focussed on intracellular processes, it becomes more needful to help students learn physiology conceptually, so that they will have a good integrative grasp of whole human body physiology. ${ }^{5}$ I will be glad to interact with my academic colleagues who continue to think through more effective ways to teach and to make learning physiology interesting and meaningful.

\section{REFERENCES}

1. Cheng HM, Damayanthi D. Misconception highlighted among medical students in the International Intermedical School Physiology Quiz. Advances in Physiology Education.2012; 36(3): 229-232.

2. Cheng HM. Thinking Through Physiology. Malaysia: Pearson, 2013.

3. Cheng HM and Hoe SZ. To pee and to poo: Cross organ principles and mechanisms in renal and gastrointestinal physiology. BLDE University Journal of Health Sciences. 2019;4: 23-27.

4. Cheng HM and Jusof F. Defining Physiology: Principles, Themes, Concepts. Cardiovascular, Respiratory and Renal Physiology. Springer, 2018.

5. Cheng HM. Conceptual Learning in Physiology. 2014. Malaysia,Pearson. 